\title{
Judicial dialogue and fundamental freedoms: The main features of an established judicial trend ${ }^{*}$
}

\author{
di Michele Di Bari ** \\ (15 ottobre 2018)
}

Summary: 1 . Introduction. -2 . A premise to the dialogue. -3 . Different trends. -4 . The attitudinal factor: the case of the US Supreme Court. -5 . The strategic factor. -6 . The normative factor. -7 . Dialogue as cooperation: The European system of protection. -8 . Concluding remarks.

\begin{abstract}
:
This article analyses the phenomenon commonly referred to as 'judicial dialogue' with the aim of describing its relevant aspects and its importance in the definition and protection of fundamental freedoms, in particular when minority rights are at stake. This contribution offers an overview of those factors influencing judges' attitude toward the use of foreign case law in the elaboration of their decision. A reference to the European system of protection of human rights is made in order to demonstrate how judicial dialogue is framed in terms of plurality of approaches rather than be characterized by hierarchy. The analysis also examines the issue of legitimacy elaborating on constitutionalism and the role of supreme, supranational and international Courts in democratic States. The final part considers the issue of appropriateness, i.e., it emphasizes the need for a comprehensive 'theory of rules of relevance' in relation to judicial dialogue.
\end{abstract}

Keywords (judicial dialogue; human rights; supreme courts, legitimacy)

\section{Introduction}

The ongoing process of globalization has brought about changes in economics, politics, and more generally, it has meant the beginning and development of a dialogue between different cultural traditions, which takes place at different levels and among different actors. The legal discipline is not immune from this process of values sharing. Opinions, ideas, approaches become soon familiar to every person working in a specific field ${ }^{1}$.

Judges, as other important social actors have become more and more prone to the idea of exploring new legal understandings stemming from other legal traditions. As many scholars recognize, it is now very usual for judges to refer to decisions of foreign jurisdictions, particularly, when interpreting domestic human rights guarantees ${ }^{2}$, since contemporary and modern constitutions of democratic countries similarly embody fundamental rights, and provide means of protections for their citizens.

Although these principles are embedded in their political contexts, giving these rights different meanings according to their cultural heritage, the distinction between international law and domestic law in the field of human rights is now less clear-cut than it was in the past $^{3}$.

\footnotetext{
* Scritto sottoposto a referee.

' See, M. CARTABIA, Diritti, giudizi e conflitti, in Ars Interpretandi, n. 1, 2015, pp. 33-50.

${ }^{2}$ This dialogue is particularly flourishing in the field of fundamental freedoms. Indeed, there is no other field such as human rights, where the sense of universality is so pervasive. Since the Second World War the idea that human beings are entitled to the same basic rights for their common belonging to humanity has brought to the idea that, despite cultural heritages, universal values do exist and they must be recognized worldwide. See, S. CASSESE, Fine della solitudine delle corti costituzionali, ovvero il dilemma del porcospino, in Ars Interpretandi, n. 1, 2015, pp. 21-33.

${ }^{3}$ See, J. WALDRON, The extraterritorial constitution and the interpretative relevance of international law, in Havard Law Review, vol.121, nº 7, 2008, pp. 1908-1929.
} 
Indeed, the phenomenon of borrowing and transplantation of relevant legal precedents is now very common ${ }^{4}$. As Justice Claire L'Heureux- Dubé of the Canadian Supreme Court has pointed out, this trend of citing, analyzing, relying on, or distinguish the decisions of foreign and supranational tribunals, might be associated with the idea of a true 'judicial dialogue ${ }^{5}$.

A legal provision is the literal transposition of a rule, or a value, which is not a concrete thing (though it leads to concrete consequences). It falls within the realm of intellectual activity, thus judges must preliminarily construe the meanings of these words and subsequently interpret them ${ }^{6}$. Therefore, the question on how the process of interpretation should be carried out is of crucial importance.

One possibility is represented by 'textualism'. According to this theory of statutory interpretation, the interpreter should consider the ordinary meaning of the words composing legal provisions. In doing so, the interpreter is more similar to a reader, i.e. any reference to 'history' or 'socio-political evolutions' is deemed unnecessary, since interpretation is strictly linked to the meaning a person could objectively and reasonably attribute to the words of the provision.

In contrast with 'intentionalism' - a legal theory according to which the interpreter should also consider the legislature's intentions beyond the mere literal transposition of a rule textualism opposes that it would be unreasonable to conceive a 'genuine collective intent' of representatives. Thus, considering legislative history as a tool for the interpretation of norms would offend the constitutionally mandated process of bicameralism ${ }^{7}$. In this theoretical frame, a constitutional judge is bound by the text, and creative interpretation of constitutional principles would betray his/her mandate.

A similar, though not identical line of reasoning is adopted by those who embrace 'originalism'. This approach has developed mainly in the USA ${ }^{8}$. It is possible to distinguish two subcategories of originalism, namely 'the original intent theory' and 'the original meaning theory'.

According to the former, a Supreme Court is in charge of reconstructing the intent of the drafter when interpreting constitutional provisions. Accordingly, judges should ascertain as accurately as possible what drafters meant by the words they used. Therefore, clarification might be found in the legislative history of the bill but any departure from the 'true and original' meaning is not allowed.

The latter, which tends to overlap textualism to some extent, holds that the interpretation of a constitutional provision should be based on what a reasonable person, living at the

\footnotetext{
${ }^{4}$ C. McCrudden, A Common Law of Human Rights?: Transnational Judicial Conversation on Constitutional Rights, Oxford Journal of Legal Studies, vol.20, $\mathrm{n}^{\circ} 4,2000$, p.501. As the author suggests, although most post-Second World War constitutions have specifically laid down elements which set them apart, most of them also have a common core of human rights provisions that are strikingly similar; they often derive from the Universal Declaration of Human Rights, the European Convention on Human Rights, the Inter-American Convention on Human Rights, and the two United Nations Covenants of 1966.

${ }^{5}$ C. L'Heureux-Dubé, The importance of Dialogue: Globalization and the International Impact of the Rehnquist Court, in Tulsa Law Journal, vol.34, 1998, p.15.

${ }^{6}$ A. BARAK, Hermeneutics and Constitutional Interpretation, in M. RosenfeLd (ed.), Ibid, p.253.

7 J.F. Manning, Textualism as a Nondelegation Doctrine, in Columbia Law Review, vol. 97, n.3, 1997, pp.674677. See also, J. F. MAnning, Textualism and Legislative Intent, in Virginia Law Review, vol. 91, 2005, pp.419-420; E. M. DavIs, The Newer Textualism: Justice Alito's statutory interpretation, in Harvard Journal of Law \& Public Policy, vol.30, n. 3, 2007, p.988.

${ }^{8}$ In the U.S., Justices of the Supreme Court Hugo Black, Antonin Scalia, and Clarence Thomas have embraced this theory. The term "originalism" has been most commonly used since the middle 1980s Earlier discussions often used the term 'interpretativism' to denote theories that sought to derive meaning from the constitutional text alone ('textualism'), or from the intentions of the originators ('intentionalism'). See, J. H. ELY, Democracy and Distrust: a Theory of Judicial Review, Harvard University Press, Cambridge, reprinted version in 2002; G. BASSHAM, Original Intent and the Constitution, Rowman \& Littlefield Publisher, New York, 1992.
} 
time of its adoption, would have conceived as the actual meaning of the used words ${ }^{9}$.

In both cases, originalism is a principle of interpretation that imposes constitutional courts to discover 'the original truth' of the constitution.

The preservation of the legal system, the safeguard of the status quo is the primary aim of this theoretical approach. Thus, judges are not supposed to create, amend, or interpret laws entering into conflict with the legislative branch. Consequently, the constitutional meanings of norms might not undergo an evolution adhering to transformations in society, neither be considered in the light of (subsequently elaborated) international standards.

Thus, if the focal point of the interpretative reasoning rests on the framers' conception, judicial review (but also the legislative power) cannot legitimately enhance the scope of application of constitutional provisions maintaining their literal form. As a result, constitutional amendments would be necessary each time a new social demand has emerged.

Nonetheless, according to a significant part of the legal doctrine, the meaning of constitutional provisions might change over the time given that a Constitution should be understood as a 'living instrument'.

Conceiving the Constitution as a 'living constitution ${ }^{10}$, allows the text to be adaptable to modern issues without forcing the legislative to pass new amendments (which are indeed procedurally complex and often require greater parliamentary majority). According to this perspective, Constitution are phrased in broad and flexible terms in order to promote a dynamic understanding of constitutional provisions.

Although accompanied by criticism by part of the legal scholarship, this conceptualization of the constitutional text has been effectively embraced by Courts. Particularly in the European scenario, national, supranational and international Courts have adhered to this line of reasoning, specifically in the field of fundamental rights protection $^{11}$.

This notion follows the idea that fundamental freedoms might undergo transformation through reinterpretation, to the extent that even those claims previously considered unconceivable can find protection.

Adopting Dworkin's classification, while rules possess their 'own rigidity' as far as they identify concrete procedural aspects, principles are in need of interpretation due to their nature as general principles ${ }^{12}$. A constitutional judge is, therefore, in charge of operating a pragmatic recognition of changes in society in order to reconcile abstract literal provisions to concrete cases $^{13}$.

\footnotetext{
${ }^{9}$ L.J. StRANG, The clash of rival and incompatible philosophical traditions within constitutional interpretation: originalism grounded in the central western philosophical tradition, in Harvard Journal of Law \& Public Policy, vol. 28, n. 3, 2005, pp. 909-910. See also, K. E. WhitTIngton, Constitutional Interpretation: Textual Meaning, Original Intent, and Judicial Review, Lawrence, University Press of Kansas, 2001, pp.30ss.

${ }^{10}$ See, D. A. Strauss, The Living Constitution, Oxford University Press, 2010, p. 33.

${ }^{11}$ A. Mowbray, The Creativity of the European Court of Human Rights, in Human Rights Law Review, vol.5, $\mathrm{n}$. 1, pp. 60-71; J. Goldsworthy, T. Campbell, Judicial Power, Democracy and Legal Positivism, Dartmouth, Aldershot, 2000; G. MORBIDELLI, Ibid, pp.173-175.

${ }^{12}$ R. DworkIN, I diritti presi sul serio, translated by G. Rebuffa, II Mulino, Bologna, 1982, p. 82.

${ }^{13}$ Sociology of law might be helpful in explaining this approach. Legal sociology is perceived as either a subdiscipline of sociology or an interdisciplinary approach to legal studies. In very general terms, it might be argued that sociology observes society and those interactions occurring between social actors (both at individual and institutional levels). As for all the other social sciences, sociology uses both empirical investigation and critical analysis in order to refine knowledge about human social activities. The important contribution of sociology in the legal knowledge is to be found in both the possibility to comprehend how legal provisions represent a given society, and how societal understanding of normative values shape the attitude of the competent social actors (mainly, but not only, judges) in the interpretation of the law. Sociology tries to answer the question about the function of law in relation to social systems, i.e. how problems in society might be solved adopting different legal provisions. See, A. FEBBrAJo, Sociologia del diritto, II Mulino, Bologna, 2009, pp.31-37.; A. Comte, A Dictionary of Sociology (3rd ed.), J. ScotT \& G. MARShALL (eds), Oxford University Press, 2005; D. Ashley, D.M. OREnsteIn, Sociological theory: Classical statements (6th ed.).
} 
Circulation of legal model, i.e., the possibility to introduce internally legal solutions that other countries have already experimented, is today a common practice ${ }^{14}$. One example of 'domestication' of foreign models is represented by the centralized control of constitutionality, first introduced in the Austrian Constitution in 1920, and then imported within the constitutional architecture of several countries ${ }^{15}$.

However, while it might be easy to recognize the origin of a model and then its transposition in other legal orders, it might be uneasy to verify whether a judge has been inspired by foreign case law when adopting a decision.

Indeed, judges do not always refer directly to their foreign colleagues, thus it might be arduous to establish whether there exists a conceptual link between two judgments. In this context, comparison requires a careful speculation to understand the reality behind judicial lines of reasoning.

This article will not offer an exhaustive examination of 'judicial dialogue' since it would be an enormous comparative effort requiring much more time and space that I am allowed to use in this analysis. However, the aim of this analysis is to underline how there exists a trend among domestic, supranational (I will refer in particular to the European Court of Justice), and international court (particularly the European Court of Human Rights) of using foreign jurisprudence as a source of inspiration for the resolution of substantial legal issues such as the definition of fundamental freedoms.

Therefore, the focus will be mainly centered on judges' attitude toward externally defined standards, and the reasons behind the development of this dialogic process. Conversely, a specific reference will be provided on judicial skepticism (the case of United States Supreme Court) toward the use foreign sources.

As suggested by McCrudden ${ }^{16}$, jurisdictions tend to fall into one of two different sorts: those which (in general) do not use foreign law (the US approach will be analyzed), and those which do so explicitly (e.g. Portugal ${ }^{17}$.).

In addition, it is important to clarify that the use of the word 'dialogue' in this specific context should not be confused with the idea of 'deliberation' where two or more actors achieve a final conclusion through an open and direct debate.

Since there is no such a process of deliberation between judiciaries, which are embedded in their own legal systems, the meaning of dialogue has to be differently understood. In other words, judicial dialogue, in this context, means the possibility for judges to analyze how in other jurisdiction a particular problem has been disentangled and applying the same logic for the resolution of their cases either implicitly or explicitly.

\section{A premise to the dialogue}

Democratic regimes encompass a series of different mechanisms and institutions aimed at preserving the 'civic cohabitation' of several individuals' and groups' social instances ${ }^{18}$.

\footnotetext{
Boston, MA, USA: Pearson Education, 2005, pp. 3-5, 32-36.

${ }^{14}$ A Pizzorusso, Sistemi Giuridici Comparati, Milano, Giuffre, 1995, p.144.

${ }^{15}$ G.F. Ferrari and A. Gambaro, Le Corti nazionali ed il diritto comparato, Una premessa, eds G.F. FERRARI AND A. GAmbaro, Corti nazionali e comparazione giuridica (Collana 50 anni della Corte Costituzionale), Edizioni Scientifiche, 2006, p. VII.

${ }^{16}$ C. McCRUDDEN, supra note 4, p.511.

17 One example is represented by judgment n. 359/2009, delivered on 9 July 2009 by the Tribunal Constitucional. The Portuguese constitutional Court - in its elaboration - has extensively recalled foreign national examples (the U.S., Canada, South Africa, Germany, Spain, etc) and both the ECtHR' s and and the ECJ's case law in order to establish whether the Portuguese constitution essentially imposes the same treatment for opposite and same-sex unions. See, E. SoRDA, Same-sex marriage: il caso portoghese, in lanus, n.4, 2011, pp.173 ss; E. CRIVELLI, II matrimonio omosessuale e la ripartizione di competenze fra legislatore e organo di giustizia costituzionale: spunti da una recente decisione del Tribunale costituzionale portoghese, in www.rivistaaic.it, 2010.

${ }^{18}$ As has been argued by Whitehead, "democracy has some indispensable components without which the
} 
Although interests in society might compete for their establishment as social and legal norms, the democratic structure allows this competition to be carried on within a given set of rules.

Liberal polities are thus constructed following the bedrock of separation of powers. In very general terms, the legislative is in charge of making laws, the executive implement them through its administrative branches, and the judiciary applies them in case of disputes.

There exists no accepted definition of 'democracy' since in both political science and legal doctrine a number of different explanations might be associated with the phenomenon 'democracy'19. However, in the modern idea of democracy ${ }^{20}$, fundamental rights and their protection have also become one the relevant elements to classify a regime as a democratic one ${ }^{21}$.

The democratic process of legislating needs to be built according to a predefined set of rules in order to provide legitimacy. The perception of legitimacy stems from the recognition of a 'common frame' around which each and every social instance is formed, discussed, and eventually rejected or developed as a new legal instrument responding to need of a social claim. This 'common frame' is provided by the constitution at national levels, and by Charter of rights at international levels.

In this context, it might seem that participation would play - alone - the key role in ensuring that societal demands are addressed properly. As long as electoral systems provide for the possibility of changing majority, and 'the people' is entitled to decide who will govern, there should be no concern.

Nonetheless, in the contemporary debate about democracy and fundamental rights it is accepted that basic constitutional guarantees are not per se sufficient.

As in the case of minority groups, it is possible that some groups' interests are marginalized if the governing majority is not willing to deal with them appropriately. It is better to clarify that the reference to minorities in this context is not meant to refer to an electoral minority (e.g. a potential parliamentary opposition which might become a majority in the next electoral turn), but instead it indicates a social group whose member are numerically unable to create a political majority.

In this case, in democratic regimes constitutions and international supervision (provided for by international human rights Courts) offer means of protection through institutional mechanisms aimed at promoting and protecting minority groups' interests.

However, despite those mechanisms constitutionally constructed for those belonging to specific minorities, there is a number of social instances which could be left apart by political parties, and thus disregarded and never addressed by the governing majority, despite changes in the political majority over the time.

In this case, since, as underlined above, the protection of fundamental rights remains an essential feature of democracy, the role of national constitutional judges and international

concept would be vacuous". However those components are not stagnating and can be differently arranged. One of such components is elections. Many political scientists have also regarded democracy as a system where the "most powerful collective decision makers are selected through fair, honest and periodic elections". This electoralist approach has found many followers, especially before the 1990s. Further on the scholars of democracy have started including features corresponding to the established industrial democracy, which entails certain political, economic, and social features associated with social rights and the idea of welfare. See, L. WhITEHEAD, Democratization, Theory and Experience, Oxford University Press, Oxford, 2002, p.20; S.P. Huntington, The Third Wave: Democratization in the Late Twentieth Century. University of Oklahoma Press, Norman, 1991, p.7.

${ }^{19}$ According to Dahl, democracy (ideally) is a form of government that provides opportunities for: 1) effective participation; 2) equality in voting; 3) gaining enlightened understanding; 4) exercising final control over the agenda; 5) inclusion of adults. R. DAHL, On Democracy, Yale University Press, New Haven, 1998, p. 38.

${ }^{20}$ D. HeLd, Models of Democracy, Polity Press, Oxford, 1987, p.2.

${ }^{21}$ A. J. LANGloIs, Human Rights without Democracy? A Critique of the Separationist Thesis, in Human Rights Quarterly, vol. 25, n 4, 2003, p.1019. 
Courts has become more and more important in the interpretation and de facto application of fundamental rights through case law.

Supreme Courts, as well as supranational Courts (have) play(ed) in this context a specific role of protecting, even irrespective of the will of the majority (non-majoritarian decisions), the rights of those who are unable to bring their claims directly to the legislative through elections.

The idea that Courts should have a fundamentla role in contemporary democracies must be understood within the theoretical frame of constitutionalism. Thus it is necessary to understand the process leading to the formation of contemporary democratic constitutions $^{22}$, the establishment of Supreme Courts (and, subsequently international Courts for the protection of human rights), whose competence is to preserve the constitutional order and ensure the protection of fundamental rights as enshrined in the constitution through their 'evolving' interpretation over the time.

Constitutionalism is usually approached from a historical, philosophical, political, and legal perspective since this phenomenon can be observed noting how its evolution has been influenced by the socio-political and cultural environment in which it has been developing.

Providing a comprehensive explanation of constitutionalism able to explain exhaustively its theoretical complexity through the investigation of the influence of each discipline mentioned above would be extremely arduous and would constitute a separate analysis. Nevertheless, in order to provide the necessary theoretical background explaining the context in which Courts have been created and now operates, thus 'grasping the structure' of the speculative frame leading to their establishment, it is possible to focus narrowly on some specific theoretical points developed in the western philosophical, political, and legal tradition $^{23}$.

Simplifying at the extreme, the features of contemporary democratic constitutional orders - stemming from the development of constitutionalism - can be identified in: (1) an autonomous public sphere, i.e. politics is secularized and distinct from religion; (2) citizenship is the premise for being part of society, and from citizenship stems the set of rights an individual is entitled to ${ }^{24}$; (3) fundamental rights are those values around which the collectivity recognizes itself; the task of protecting these rights is attributed to autonomous organs, usually a constitutional court ${ }^{25}$; $(4)$ the exercise of power is legitimate

\footnotetext{
${ }^{22}$ Western democratic countries are all characterized by the fact of possessing a written constitution. One exception is represented by the United Kingdom which does not have a written constitution but it is nonetheless characterized by a set of law and principle with constitutional character. In addition, in 2005 in the United Kingdom was established a Supreme Court whose task is also to verify whether primary legislation compatible with the rights contained in the European Convention on Human Rights (the Court cannot overturn primary legislation, but in case it declares incompatibility with the ECHR, this declaration [section 10 of the Human Rights Act 1998] allows ministers to amend the legislation by statutory instrument to remove the incompatibility).

${ }^{23}$ Since this research is concerned with those legal developments occurring in the European Union, both at national and supranational level, no reference is made to other constitutional tradition, e.g. the process leading to the adoption of constitutions in the Islamic world.

${ }^{24}$ The recognition of some basic rights is also granted to non-citizens in contemporary democracy. Indeed, it is now accepted that aliens are also entitled to some fundamental rights, i.e. the right to life, since they are considered firstly as individuals.

${ }^{25}$ The declaration of unconstitutionality of legal provisions is regulated differently from country to country. There is usually a distinction to be made between common law and civil law systems. In the former case it is possible for ordinary judges to declare the constitutionality of a provisions. In the second case there is an ad hoc organ, i.e. a Constitutional Court. Where there exist a Constitutional Court judicial review might intervene before the entrance into force of a law (e.g. in France with the Conseil Constitutionnel) or after. In addition, while in some countries, e.g. Italy, ordinary judges cannot directly deal with the issue of constitutionality, in others, as in the United States there is a mixed model of judicial review since both ordinary judges and the Supreme Court might scrutinize the compatibility of a statute with the constitution. For a comprehensive explanation of each of the models of judicial review, see G.DE VERGOTTINI, Diritto costituzionale comparato. Cedam, Padova, 2010.
} 
because it stems from 'the will of the people' and it is lawful to the extent it respects the procedural rules established according to the constitution; (5) the separation of powers in a system of checks and balances is integrated in the constitution ${ }^{26}$.

These features might be observed, with some distinctions, in all democratic countries. These structural constitutional characteristics represent the result of the influence of two main schools of philosophical thoughts, namely the Anglo-Saxon (common law) and the continental (civil law) constitutional traditions. These two competing ideas of the State and the citizen have been the most influential 'theoretical engine' for the elaboration of modern and contemporary constitutions. The analysis of western constitutions shows, indeed, how constitutional designs adhere to one or the other conception or even to both.

Both conceptions refer to the theory of 'the social contract ${ }^{27}$ ', but their understanding of the reasons leading to the formation of the social contract and of its contents is different. These differences have led to a different elaboration of the consequences of this contract, thus, consequently to a different constitutional design.

Unlike Thomas Hobbes, who assumed that human beings needed absolute monarchy to govern their malicious attitude toward each other, Locke believed that human nature is characterized by reason and tolerance ${ }^{28}$. Like Hobbes, Locke believed that human nature allowed men to be selfish. In a natural state all people were equal and independent, and everyone had a natural right to defend his life, health, liberty, or possessions ${ }^{29}$.

According to Locke the state must protect its citizens, and in case this task is not performed, or whether governmental authorities abuse of their powers, revolution is a right individuals should exercise ${ }^{30}$. In accordance with the Lockean idea of the State, Montesquieu, Hamilton, Madison, Jay, and Tocqueville subsequently elaborated their theorization of the liberal state.

Tocqueville in his famous De la Démocratie in Amérique, firstly emphasized how putting too much emphasis on parliamentarism and the majoritarian principle would have meant to disregard the risk of a new kind of authoritarianism represented by the dictatorship of the majority ${ }^{31}$. Thus, subsequently the liberal state was thought and designed bearing in mind that individuals are entitled to some basic rights exercised through their representatives and protected by the separation of powers. Parliamentarism, the majoritarian principle, the separation of powers, have become the main features of this new idea of constitutional structure.

While the Anglo-Saxon philosophical tradition has influenced the United States and the British legal systems ${ }^{32}$, in continental Europe constitutionalism has been characterized

\footnotetext{
${ }^{26}$ A. BARBERA, Le basi filosofiche del costituzionalismo, in Le basi fisolofiche del costituzionalismo, Laterza, Milano, 2005, pp.4-5.

${ }^{27}$ The 'social contract' is an intellectual construct used to explain how society has been created in history and how the process of attributing power to governments has occurred. According to theorists of the social contract, the process leading to the formation of the contract was characterized by mutual consent of contractors (individuals at the state of nature). The aim of this agreement was to create a set of common rules, accepting corresponding duties, in order to prevent violence and harms in society. Social contract theory played an important role in the emergence of the idea that political authority must be derived from the consent of the governed. See, D. Boucher, P. Kelly, The Social Contract from Hobbes to Rawls, Routledge, New York, 1994.

${ }^{28}$ See, J. LockE, Lettera sulla tolleranza, Laterza, Bari-Roma, 2008.

29 The idea of natural rights has been elaborated since Thomas Aquinas, then reconstructed by Grotius, Pufendorf, Hobbes, Locke, and all the other philosophers conceiving fundamental rights as grounded not in rationality but in nature. On this point, see, A. ANDREATTA, A. Enzo BALDINI, II pensiero politico dell'età moderna, Utet, Torino, 1999; B. CONSTANT, La libertà degli antichi paragonata a quella dei moderni, Liberilibri, Macerata, 2001; M. D'AdDIo, Storia delle dottrine politiche. E.C.I.G., Genova, 2002;. B. TIERNEY, L'idea dei diritti naturali, legge naturale e diritto canonico, in Rivista di Studi Politici Internazionali, vol. 71 , no 1 , (2004), (pp.1150-1625); F. TODESCAN, Compendio di storia della filosofia del diritto. Cedam, Padova, 2009.

${ }^{30}$ N. BobBIO, L'eta dei diritti, Torino, Giapichelli, 1997, pp.60-61.

${ }^{31}$ See S. ChIGNOLA, Fragile cristallo. Per la storia del concetto di società, Editoriale scientifica, Napoli, 2004.

${ }^{32}$ The United Kingdom also adheres to the typical Rousseauian conception of supremacy of the parliament.
} 
mainly by the theoretical work of Jean-Jacques Rousseau. Although Rousseau shares with Locke and Hobbes the contrattualistic nature of the State, their understanding of the reasons bringing together individuals for the stipulation of the social contract and its results are different.

In Rousseau's theory, in the state of nature individuals were isolated and dispersed without a structured community and they freely decided to create a community without abandoning their freedom for the sake of their wellness. In Rousseau, the social contract is not a 'pactum subjectionis' as in Hobbes but rather a 'pactum unionis'. In this scheme, individuals are not separated from the State. The community, its members as citizens are the nation. Thus, in Rousseau the separation between State a citizens is overcome in favor of vision that perceives the social contract as the moment in which an individual gives up his rights as a uti singulus and receive them back as a utis civis ${ }^{33}$.

Democracy is established as a direct form of participation since each individual exercised his right to participate directly through the 'volonté générale'. The 'general will' is not the sum of each individuals' will, but it is something transcendent that exists within each and every human being ${ }^{34}$. The law is the concrete outcome of the general will to which all individuals participate.

This postulate has been crystallized in the Declaration of the Rights of Man and of the Citizen of 1789. Art.6 of the Declaration reads: 'La Loi est l'expression de la volonté générale. Tous les Citoyens ont droit de concourir personnellement, ou par leurs Représentans, à sa formation. Elle doit être la même pour tous, soit qu'elle protège, soit qu'elle punisse. Tous les Citoyens étant égaux à ses yeux, sont également admissibles à toutes dignités, places et emplois publics, selon leur capacité, et sans autre distinction que celle de leurs vertus et de leurs talens'35.

In this model, the parliamentary assembly plays the key role and the separation of powers is organic to the functioning of the system rather than representing a way of preventing an authoritarian drift. Government and judiciary are considered subordinate entities of the State vis-à-vis the parliament, i.e. a government is in charge as long as the parliament confers its trust, and judges must apply the law and cannot interfere with the legislative.

The underlying risks related to the general will doctrine resulted evident after the French revolution where from the aim of creating a society of equal citizens, France went through the period of the Napoleonic Empire.

From the premises of contractualism under both the Anglo-Saxon and continental traditions of the $17^{\text {th }}$ and $18^{\text {th }}$ century, the philosophical elaboration concerning constitutionalism has developed in the $19^{\text {th }}$ and $20^{\text {th }}$ century with the fundamental contribution of Hans Kelsen. This prominent scholar, who personally participated in the elaboration of the Austrian constitution (1920), conceived the Constitution as the 'top' and the 'centre' of a legal order ${ }^{36}$. A fundamental norm encompassing those values typical of a given political community (written down in the text as of fundamental rights), and 'the zenith' of the legal order since no legal provision might contrast with constitutional provisions. In this pyramidal scheme hierarchy governs the legal system from the top to

\footnotetext{
Evidences can be found in the impossibility for the judiciary, also for the newly created Supreme Court to overturn primary legislation. See note 6.

${ }^{33}$ F Todescan, Etiamsi Daremus, Studi Sinfonici sul Diritto Naturale, Cedam, Padova, 2003 p.199.

${ }^{34}$ J. Swenson, On Jean-Jacques Rousseau, Stanford University Press, Stanford, 2000, p. 162.

${ }^{35}$ This conception seems to be all-comprehensive since no one can be excluded from the formation of the general will because the general will stems from everyone. However, as underlined by Hannah Arendt in her 'The Origin of Totalitarianism' this theoretical frame has supplied the intellectual basis for the formation of totalitarian regimes. In concreto, on the premise that no one could oppose the general will, once a majority has established its rule, opposing it means contrasting the general will. See, H. ARENDT, Le Origini del Totalitarismo, Einaudi, Torino, 2004.

${ }^{36}$ H. KelSEN, I fondamenti della democrazia, in H. KelSEN, La democrazia, II Mulino, Bologna, 1981, p.154
} 
the bottom.

Kelsen's main concern was to design a system in which the issue previously underlined by Tocqueville, that is majoritarian despotism, could be overcome by introducing a new constraint on the exercise of power by representative bodies, namely a constitutional judge. In contrast with Schmitt ${ }^{37}$, who rejected the idea of a constitutional Court as guardian of the constitution against the will of political majorities, Kelsen argued that a democratic system needs a constitutional judge.

In his view, since it would be unlikely to expect impartiality by a derivation of a majority (e.g. parliament or government), a judicial body is better equipped to provide an impartial decision over issue concerning legitimacy and constitutionality of institutional acts ${ }^{38}$.

Given that the number of socio-political problems might conduct to institutional conflicts on 'whether', 'when', and 'how' it is appropriate to address them, the Constitution represents the ideal device able to prevent or solve clashes between competing identities and interests.

In this environment, a supreme Court plays an essential role in defining, limiting, or prompting the answers of representative authorities.

Indeed, as Rosenfeld observed, there would be no reason to impose a Constitution if a society was peacefully homogeneous so that interests are the same for each and every member of society ${ }^{39}$. In this context, not only national supreme Courts might play a crucial role, also supranational/international Courts, given that non-national Courts are not influenced by electoral majorities.

\section{Different trends}

The past few decades have witnessed an increase in the number of domestic tribunals referring to international and foreign legal sources to inform their interpretation of domestic law. In particular, constitutional Courts are now familiar with the idea of looking for guidance - when ruling on particular substantive legal issues - to the decisions taken in other jurisdictions, either at national, supranational or international level.

Equally, supranational and international tribunals faced with analogous legal issues might refer to domestic courts' decisions ${ }^{40}$. According to Krisch, the reasons influencing this dialogic process between Courts are mainly three: attitudinal, normative, and strategic ${ }^{41}$.

The attitudinal factor refers to the behavior of judges in relation to their political view, i.e. it is assumed that, on average, conservative judges should have a stronger nationalist attitude that make them more skeptical over the possibility to look at foreign case law, while left-leaning judges should be more inclined towards judicial dialogue (in terms of referring to outside sources) $)^{42}$.

The strategic factor regards the possibility to favor or contrast judicial dialogue in order to obtain legitimacy or, conversely, strengthening the position and the authority of the court as an autonomous institution ${ }^{43}$.

\footnotetext{
${ }^{37}$ See, C. Schmitt, Constitutional Theory. Jefrrey SeITZER, trans., London, Duke University Press, 2007; M. NicoletTI, Trascendenza e potere. La teologia politica di Carl Schmitt, Morcelliana, Brescia, 2002.

${ }^{38} \mathrm{H}$. KELSEN, La garanzia giurisdizionale della costituzione, in H. KELSEN, La giustizia costituzionale, Giuffrè, Milano, 1981, p.277.

${ }_{39}$ M. Rosenfeld, Modern Constitutionalism, in M. Rosenfeld (ed.), Identity, Difference, and Legitimacy, Theoretical perspectives, Duke University Press, London, 1994, p.5.

${ }^{40}$ See A.M. SLAUGHTER, Judicial Globalization, in Virginia Journal of International Law, vol.40, 2000, p.1105.

${ }^{41} \mathrm{~N}$. KRISCH, Open Architecture of European Human Rights Law, in The Modern Law Review, vol.71, n.2, 2008.

${ }^{42}$ See the American study by J.A. Segal and H.J. SPAETH, The Supreme Court and the Attitudinal Model, New York, Cambridge University Press, 2000.

${ }^{43}$ L.R. Helfer and A.M. SLAUghter, Toward A Theory of Effective Supranational Adjudication, in Yale Law Journal, vol. 107, n.2, 1997, p.273.
} 
The normative factor is related to the judges' cultural heritages, i.e., the attitude of judges would be shaped by their internalization and socialization of constitutional settings. For instance, if the predominant idea among judges is that of parliamentary supremacy, it is more likely that this will lead to some skepticism as regard to the possibility to refer to foreign jurisprudence or to accept supranational supremacy claims ${ }^{44}$.

\section{The attitudinal factor: the case of the US Supreme Court}

The attitudinal factor is able to explain the US Supreme Court's approach to the global judicial dialogue. The American exceptionalism has not only characterized the US politics over the centuries, but also its jurisprudence.

According to this preliminary consideration, it is not surprising to discover that US judges have rarely relied on foreign legal perspectives, preferring an ethnocentric approach in the resolution of their legal disputes. Indeed, the Supreme Court has developed what is commonly referred to as 'originalism' to limit the creativity of judges when interpreting the law. However, even the US judiciary has occasionally regarded foreign provisions and the related case law when dealing with specific legal issues ${ }^{45}$.

In particular, despite its generally conservative attitude toward the possibility of using other legal sources than those deriving from the American legal tradition, it is possible to find cases where Supreme Justices recalled foreign precedents. In New York $v$. United States for instances, Justice Frankfurter recalled the Argentinean legislation and the constitution of Australia and Canada when defining the concept of solidarity among federal units $^{46}$. In addition, concepts as 'practice of civilized nations ${ }^{47}$,' 'standards of decency in a civilized society ${ }^{48}$, 'nations of justice of English people speaking ${ }^{49}$ ' can be found in the American jurisprudence as evidence of a certain margin of attention to the comparative method, when framing the reasoning behind judgments with a particular social impact.

Indeed, from the 1990s onward, the Supreme Court has shown a greater concern to other legal traditions. In Parenthood $v$. Casey ${ }^{50}$, Justice Rehnquist made specific and direct reference in his dissenting opinion to the case law of both the Canadian Supreme Court and the German Constitutional Court (Bundesverfassungsgericht). In Atkins v. Virginia ${ }^{51}$, overruling a previous decision of $1989^{52}$, the Court with a majority of six votes to three declared unconstitutional the death penalty in those cases involving people with mental disability.

In this ruling it was stated that, unlike provisions of the Constitution, the Eighth Amendment should be interpreted in light of the 'evolving standards of decency that mark the progress of a maturing society'. Justice Stevens, quoting as amicus curies a Brief from the European Union highlighted how within the world community, the imposition of the death penalty for crimes committed by mentally retarded offenders is overwhelmingly disapproved ${ }^{53}$.

In this judgment it is possible to recognize two different trends within the Court. One

\footnotetext{
${ }^{44} \mathrm{~N}$. KRISCH, Ibidem, p.212. anni della Corte Costituzionale), Edizioni Scientifiche, 2006, p.310.

${ }^{46}$ New York v. United States, 326 U.S. 572 (1946).

${ }^{47}$ Roe v. Wade, 410 U.S. 113, 130 (1972).

${ }^{48}$ Bowers v. Hardwick, 478 U.S. 197 (1986).

${ }^{49}$ Rochin v. California, 342 U.S. 165 (1952), concurring opinion Justice Frankfurter.

${ }^{50}$ Planned Parenthood v. Casey, 505 U.S. 833 (1992)

${ }^{51}$ Atkins v. Virginia, 536 U.S. 304 (2002).

${ }_{52}$ Penry v. Lynaugh, 492 U.S. 302 (1989).

${ }^{53}$ Atkins v. Virginia, 536 U.S. 321, (2002) Justice Stevens, Opinion of the Court.
}

${ }^{45}$ In Michigan (1860), Wisconsin (1864), and Illinois (1978), judges did consider French commercial law when deciding upon their cases; this might be possibly justified by the fact that in these territories French legislation has been influential during the XVIII century. See, G. F. Ferrari, La comparazione giuridica negli Stati Uniti d'America, eds G.F. FERRARI and A. GAMBARO, Corti nazionali e comparazione giuridica (Collana 50 
represented by Justice Stevens, whose opinion was that it is possible to recall foreign jurisprudence in order to establish 'civilized standards', and the one represented by Chief Justice Rehnquist who disapproved the possibility to evoke outside law. In his dissenting opinion, Justice Rehnquist condemned any reference to foreign law stating clearly that "... the Court's suggestion that these sources are relevant to the constitutional question finds little support in our precedents and, in my view, is antithetical to considerations of federalism, which instruct that any "permanent prohibition upon all units of democratic government must [be apparent] in the operative acts (laws and the application of laws) that the people have approved ${ }^{54} \ldots .$.

Again, in 2005, the Court showed its internal contradictions, i.e. the tension between conservative judges and more progressive ones, in relation to the possibility to use principles flourishing in foreign jurisdictions. In Roper $v$. Simmons ${ }^{55}$ the Supreme Court held that it was unconstitutional to impose capital punishment for crimes committed while under the age of 18.

With a majority of five votes to four, this decision overruled the 1989 decision taken in Stanford $v$. Kentucky ${ }^{56}$ where Justice Scalia strongly opposed the use of outside jurisprudence arguing that "while the practices of other nations, particularly other democracies, can be relevant to determining whether a practice uniform among our people, it is not merely a historical accident, but rather 'so implicit in the concept of order liberty', [nevertheless], they cannot serve to establish the first Eighth Amendment prerequisite, that practice is accepted among our people. ${ }^{57 "}$.

In Roper, Supreme Justices considered not only the American Constitution and legal tradition, but also the practices of other countries to support the holding. In particular, Justice Kennedy noted how between 1990 and the time of the case, only seven countries other than the United States had executed juvenile offenders (Iran, Pakistan, Saudi Arabia, Yemen, Nigeria, the Democratic Republic of Congo, and China). In addition, each of those countries since 1990 had either abolished the death penalty for juveniles or made public disavowal of this practice, leaving the United States the only country allowing execution of juvenile offenders ${ }^{58}$. The majority of the Court went further arguing that only the United States and Somalia had not ratified the United Nations Convention on the Rights of the Child whose Art.37 explicitly provides for a ban of capital punishment in cases involving juveniles.

As in the case of Atkins, the Court was divided in two separate lines of reasoning. In fact, if on the one hand the majority was convinced that it was justified and appropriate to underline the practice of other nations and drew a decision according also to these findings, on the other hand the minority of the Court strongly opposed this comparative method. In Justice Scalia's dissenting opinion the main criticism is made in relation to the practice of taking guidance from foreign law when interpreting the American Constitution. In particular, Justice Scalia not only questioned the relevance of foreign law but also accused the Court of 'invoking alien law when it agrees one's own thinking, and ignoring it otherwise ${ }^{59}$.

\footnotetext{
${ }^{54}$ Ibidem, Dissenting Opinion Chief Justice Rehnquist.

55 Roper v. Simmons, 543 U.S. 551 (2005). In drawing the line at 18 years of age for actions with death eligibility, the Supreme Court considered that 18 is also where the law draws the line between minority and adulthood for a multitude of other purposes, overturning its holding in Stanford $v$. Kentucky that such a consideration was irrelevant.

56 Stanford v. Kentucky, 492 U.S. 361 (1989). In this judgment, the Court upheld capital punishment on offenders above or at the age of 16.

${ }^{57}$ Ibidem, Dissenting Opinion, Justice Scalia.

${ }^{58}$ Roper v. Simmons, 543 U.S. 551 (2005), Justice Kennedy, Opinion of the Court.

59 Justice Scalia argued that the Court exists to rule on what the law says, not what it should say, and that it is for the legislature, acting in the manner prescribed in Article $\mathrm{V}$ of the Constitution, to offer amendments to the Constitution in light of the evolving standard of decency, not for the Court to arbitrarily make de
} 


\section{The strategic factor}

According to Slaughter 'the process of borrowing' results from more than just the need for legal sources, i.e., there would be significant political reasons behind the incorporation, through jurisprudence, of outside legal norms. This might be particularly true for those countries such as South Africa, in which there was a need to demonstrate the nation's renewed commitment to civil rights ${ }^{60}$. Similar attitude toward 'judicial openness' might be related to the desire of entering in the international dialogue to increase the influence over the creation of international norms ${ }^{61}$.

For instance, the Spanish Tribunal Constitucional (TC) has developed a strong attitude toward the possibility to use foreign jurisprudence as a source of inspiration for its pronouncements. Nevertheless, this predisposition has decreased with the affirmation of the TC as a legitimate authority within the Spanish legal order, according to what Krish would call a strategic approach. Indeed, during its first years, The TC has been heavily inspired by the Italian Constitutional Court. For instance, In defining the principle of freedom of association enshrined in Art. 21 of the Spanish Constitution, the TC has made explicit reference to the Italian case law, arguing that "Tales defectos no puede autorizar a realizar la reunión a ultranza, dando charácter al derecho de reunión [...] como determinó la Sentencia 54/1961 de la Corte Constitutional Italiana ${ }^{62}$. The TC has also been strongly influenced by the European Court Human Rights' (ECtHR) jurisprudence. In fact, according to art.10 (2) of the Spanish Constitution 'The norms relative to basic rights and liberties which are recognized by the Constitution shall be interpreted in conformity with the Universal Declaration of Human Rights and the international treaties and agreements on those matters ratified by Spain'. Nevertheless, as Krish suggests in his article, although the TC refers to the ECtHR as a matter of normalcy, it is now in a much less precarious position than in the early years, and this leads to the need of preserving its autonomy ${ }^{63}$.

Another important aspect to be considered, when discussing the reasons behind judicial dialogue, is the perception of the values enshrined in the Constitution. Indeed, the willingness of Constitutional Courts to look at foreign national, supranational or international case law as a source of interpretation might suggest that Constitutional judges perceives their constitutions as components of a larger body of international legal documents. In other words, fundamental principles such as human rights and democracy are conceived not simply as having a domestic character that reflects one country's society, but as universal values part of a whole that reflects a worldwide spread set of general norms ${ }^{64}$. In this direction goes Justice Kirby of the Australian Supreme Court when explaining that 'to the full extent that its text permits, Australia's Constitution...

facto amendments. Roper, Justice Scalia dissenting opinion.

${ }^{60}$ See H. K. WeBB, The Constitutional Court of South Africa: Rights Interpretation and Comparative Constitutional Law, in University of Pennsylvania Journal of Constitutional Law, Symposium Issue, vol.2, n.1, 2008, p.232.

${ }^{61}$ As L'Heureux-Dubé argues, although the ruling of any national court that deals with a substantive legal issues (such as the property of extraditing a fugitive to face death penalty) may influence other courts that deal with analogous legal questions, only courts that engage in the international judicial conversation can contribute to the definition of the predominant international judicial norm and shape the development of international law. L'Heureux-Dubé, supra note 4, at. 39.

${ }^{62}$ G. DI PLINIO, Uso del "comparato" e problemi di legittimazione nelle dinamiche della Corti costituzionali: Io stile spagnolo, eds G.F. FERRARI and A. GAMBARO, Corti nazionali e comparazione giuridica (Collana 50 anni della Corte Costituzionale), Edizioni Scientifiche, 2006, p.65-70. As the author explain, this attitude might be the result of an effort to affirm its jurisprudence by adhering to the legal tradition of a country, such as Italy, culturally similar and thus easily comparable with Spain

${ }^{63}$ N. KRISH, Ibidem, p.189.

${ }^{64}$ A.M. Slaughter, The International Judicial Dialogue: When Domestic Constitutional Courts Join the Conversation, in Harvard Law Review, vol.114, 2001, p.2063. 
accommodates itself to international law, including insofar as that law expresses basic rights. The reasons for this is that the Constitution not only speaks to the people of Australia...it also speaks to the international community as the basic law of the Australian nation which is a member of that community ${ }^{65}$.

\section{The normative factor:}

The dialogic relation between international judiciaries in the field of basic rights protection seems to be explained through the lens of what Krish refers to as normative factors, that is, the phenomenon according to which the internalization of norms, in this case international standards concerning the protection of human rights, leads to mutual coherence. Indeed, differently from domestic constitutional courts whose judgments are normally territorially constrained and only potentially influential abroad, international judges such as the ECtHR and the Inter-American Court of Human Rights (I-ACtHR) create standards which become binding for each member state of the treaty. For this reason, and considering that human rights are understood as universal values, it should be not surprising that the two regional courts have developed a very a similar behavior vis-à-vis member states and have fostered a coherent understanding of rights enshrined in the Conventions.

One example of this trend is offered by the margin of appreciation doctrine. The Strasburg Court referred to the doctrine of the margin of appreciation, in relation to Art.15 $\mathrm{ECHR}$, in Ireland v. United Kingdom. In this judgment, the Court recognized that "by reason of their direct and continuous contact with the pressing needs of the moment, the national authorities are in principle better position than the international Judge to decide both on the presence of an emergency and on the nature and the scope of derogations necessary to avert $i t^{66}$." Nonetheless, in the same pronouncement the Court delineated the limit of States' discretion in what the Court referred to as the European Supervision ${ }^{67}$. This logical approach has been also adopted by the I-ACtHR in Zambrano. The American Judge, explicitly recalling its European regional counterpart in Lawless, concluded that "It is the obligation of the State to determine the reasons and motives that lead the domestic authorities to declare a state of emergency and it is up to those authorities to exercise appropriate and effective control over the situation ${ }^{68 "}$. Furthermore, as the ECtHR, the IACtHR established that "...it is up to the Inter-American system's organs to exercise an effective control in a subsidiary and complementary manner, within the framework of their respective competencies ${ }^{69} . "$

Another example of commonalities between the ECtHR and the I-ACtHR can be found in relation to the protection against inhuman and degrading treatments. Both Courts emphasize that every type of humiliation, or treatment with varying degrees of physical and psychological effects caused by endogenous and exogenous factors fall under the scope of the guarantees provided for by the two regional Conventions. The I-ACtHR in Loayza Tamayo specified that "...the degrading aspect is characterized by the fear, anxiety and inferiority induced for the purpose of humiliating and degrading the victim and breaking his physical and moral resistance... ${ }^{70 ", ~ r e c a l l i n g ~ t h e ~ E C t H R ~ i n ~ I r e l a n d ~ v . ~ T h e ~}$

\footnotetext{
${ }^{65}$ Newcrest Mining (WA) Ltd $v$ Commonwealth, 190 CLR 513, (1997), 657-8.

${ }^{66}$ Ireland v. the United Kingdom, ECtHR, Judgment 18 January 1978, Application n' 5310/71 para.207.

${ }^{67}$ In the words of the Court "...States do not enjoy an unlimited power in this respect... the domestic margin of appreciation is thus accompanied by a European Supervision." Ireland v. United Kingdom, para. 207.

${ }^{68}$ Zambrano Vélez et al. v. Ecuador, ACtHR, Judgment of 4 July 2007., para.47.

${ }^{69} \mathrm{Ibidem}$, para.48.

70 Loayza Tamayo v. Peru, ACtHR,Judgment of 17 September 1997. In this case the Court recalled the ECtHR in Ireland v. The United Kingdom, and confirmed the interrelation between detention incomunicado and degrading treatments.
} 
United Kingdom which concluded that the so-called "five techniques" ${ }^{71}$ " constituted an inhumane and degrading practice of interrogation, in breach of Art. $3 \mathrm{ECHR}^{72}$.

\section{Dialogue as cooperation: The European system of protection}

The European system for the protection of human rights is characterized by a complex multilevel structure:

(a) the national level: constitutional/supreme courts/tribunals;

(b) the supranational level: the ECJ;

(c) the international level: the ECtHR.

Despite this differentiation, one should not conceive this seemingly vertical categorization as governed by hierarchical rules. On the contrary, this legal (dis)order represents a pluralist system in which the relationships between constituent parts are governed not by legal rules (hierarchy) but primarily by politics, often judicial politics (heterarchy $)^{73}$. In other words, the definition of rights is made by different judicial authorities institutionalized at different level, within and beyond the state ${ }^{74}$.

The EU is more than international organization but less than a federal state. As some authors describe it, the EU is a quasi-federal state ${ }^{75}$. A hybrid legal creature, whose different bodies (e.g. Parliament, Commission, ECJ, etc.) resemble those typical of a state, but whose decisional procedures vary (simple majority, qualified majority, unanimity) depending on the subject considered, give alternatively the idea of a 'Unity' or the idea of 'Diversity'. While leaving aside an analysis of the entire EU system, for this research it is necessary to understand how the mechanisms for the protection of rights function.

This system, differently from a constitutional state's order, though organized, it is not constructed according to rules typically applied to constitutional state.

At supranational and international level, the institutional architecture does not provide for a 'legislative power', and the system of check and balances is substitute by the selfrestraints of judges.

Indeed, constraints usually applied to constitutional courts do not apply to the ECJ and the ECtHR.

In order to understand the complexity of the EU scenario it is necessary to analyze how, at different levels, courts understand their role as guardians of fundamental freedoms. Thus, from a system governed by dogmatism, where predefined (constitutional) rules regulate the relationship between different actors, the system seems to move toward an order where 'the criterion of competence' is prevailing over written rules, (e.g., the ECJ is responsible to protect individuals' rights when scrutinizing EU law, while the ECtHR supervise compliance to the ECHR).

National constitutional courts have demonstrated their willingness to comply with their European counterparts' case law (either the ECJ or the ECtHR), though preserving their autonomy as independent institutions ${ }^{76}$.

\footnotetext{
${ }^{71}$ This terminology refers to certain interrogation practices adopted by the Northern Ireland and British governments during Operation Demetrius in the early 1970s. The five techniques were: wall-standing; hooding; subjection to noise; deprivation of sleep; deprivation of food and drink

${ }^{72}$ Ireland v. the United Kingdom, para.168.

${ }^{73}$ N. KRISCH, Ibid, p.185; S. Douglas-SCOTT, A Tale of two Courts: Luxemburg, Strasburg and the growing European Human Rights Acquis, in Common Market Law Review, vol.43, n. 3, 2006, (pp. 629-665), p.630 ss.

${ }^{74}$ See M. Delmas-Marty, Towards a Truly Common Law: Europe as a Laboratory for Legal Pluralism, Cambridge University Press, translated by N. Norberg, 2002, pp.14ss.

${ }_{75}^{75}$. LIEBLE, Non-Discrimination, in ERA Forum, n.10, 2009, (pp.76-89), p.78.

${ }^{76}$ Both the German and the Italian Constitutional Court have elaborated a doctrine giving the ECJ's and the ECtHR's case law an important role in the interpretation of fundamental provisions. In its judgments n. 348349, in 2007, the Corte Costituzionale has referred to the ECHR provisions and its interpretation as 'norme interposte', i.e. legal provisions whose collocation is to be found between the constitution and primary law,
} 
The idea of a dialogic process among jurisdictions in the EU stems from the observation of those interactions occurring between the ECJ and national courts. For instance, the German constitutional court has established the conceptual margins of its 'judicial relationship' through Solange I and Solange II.

In particular, while in Solange ${ }^{77}$ the German court was skeptical on the possibility for the European system to provide an adequate protection for fundamental freedoms, in Solange $I I^{78}$ the BVerfGE abandoned its reservation considering that the ECJ had developed an extensive case law in the area of fundamental rights.

Indeed, before the adoption of a EU Charter of Rights, binding for EU institutions, in the lack of EU catalogue of fundamental rights the ECJ autonomously expanded the competence of the European Community to the field of protection of human rights through judicial law-making ${ }^{79}$, particularly through judgments such as Stauder ${ }^{80}$, Internationale Handelsgesellschaft ${ }^{81}$, Nold ${ }^{82}$, and Les Verts ${ }^{83}$.

Yet, this pragmatic approach was driven by the exigency of overcoming the challenge national constitutional court could have made to the supremacy of EU law and over the competence of the ECJ.

Nonetheless, as underlined by Schimmelfennig, '[...] the ECJ became entangled in a dilemma. Binding its jurisdiction to the human rights norms of the ECHR helped to placate

thus giving these provisions supremacy over ordinary law. The German Supreme Court (Bundesverfassungsgericht, 2 BvR 1481/04) has also acknowledged that the ECtHR's judgments have to be taken into consideration, though it has clarified that these decisions may have to be integrated to fit into the domestic legal system. In addition, as shown in the analysis of the selected case law, constitutional courts have dealt with the issue of same-sex unions' legal recognition using among the interpretative parameters also the ECJ's and ECtHR's jurisprudence. See, N. PIGNATELLI, Le sentenze della Corte costituzionale nn. 348 e 349 del 2007: la dilatazione della tecnica della "interposizione" (e del giudizio costituzionale), in Quaderni Costituzionali, n.1, 2008, (pp. 140-143); C. NAPOLI, Le sentenze della Corte costituzionale nn. 348 e 349 del 2007: la nuova collocazione della CEDU e le conseguenti prospettive di dialogo tra le Corti , in Quaderni Costituzionali, n. 1, 2008, (pp. 137-139); S.M., CICCONETTI, Creazione indiretta del diritto e norme interposte, in Giurisprudenza costituzionale, n.1 , 2008. (pp. 565-575).

${ }^{77}$ In this Judgment the Court stated that: "... as long as the integration process has not progressed so far that Community law receives a catalogue of fundamental rights decided on by a parliament and of settled validity, which is adequate in comparison with the catalogue of fundamental rights contained in the Basic Law, a reference to the Federal Constitutional Court [...] is admissible and necessary [...] in so far as [EC law] conflicts with one the fundamental rights of the Basic Law". BVerfGE 37, 271: [1974] 2 CMLR 551

${ }^{78}$ In Solange II the German Court changed its attitude toward the ECJ by stating that "...As long as the European Communities, in particular the European Court case law, generally ensure effective protection of fundamental rights as against the sovereign powers of the Communities which is to be regarded as substantially similar to the protection of fundamental rights required unconditionally by the Constitution, and in so far as they general safeguard the essential content of fundamental rights, the Federal Constitutional Court will no longer exercise its jurisdiction to decide on the applicability of secondary Community legislation ..." BVerfG 73, 339: [1987] 3 CMLR 225.

${ }^{79}$ As a matter of facts, the Treaty establishing the European Community did not provide for any reference to fundamental freedoms, since the purpose of the European integration process was primarily to integrated European economies in order to promote cooperation among and between Member States. However, the judicial body of the Community, i.e. the European Court of Justice (ECJ) soon after the entry into force of the funding treaties established its authority beyond the possibility to resolve conflicts strictly related only to the implementation of economic policies. While the court's fundamental rights jurisprudence was approved by the institutions in 1977 (Joint Declaration by the European Parliament, Council and the Commission concerning the protection of fundamental rights and the ECHR [OJ C 103, 27/04/1977 P. 1-2]) and a statement to that effect was inserted into the treaties by the Maastricht Treaty, it was only in 1999 that the European Council formally went about the process of initiating the drafting a codified catalogue of fundamental rights for the EU.

${ }^{80}$ Case C-29/69, Stauder v. City of Ulm, ECJ, 12 November 1969.

${ }_{81}$ Case C-11/70 Internationale Handelsgesellschaft $v$. Einfuhrund Vorratsstelle Fuer Getreide Und Futtermittel, ECJ, 17 December 1970.

${ }^{82}$ Case C-4/73 Nold Kohlen und Baustoffgroßhandlung v. Commission of the European Communities, ECJ, 14 May 1974

${ }^{83}$ Case C-190/04, Parti écologiste 'Les Verts' v European Parliament, ECJ, o25 February 1988. 
national constitutional courts but made it difficult to refuse the formal adherence of the European Community (EC) to the ECHR. As much as it could entrap national constitutional courts to accept the supremacy of the ECJ with regard to Community law, the ECJ was entrapped itself to acknowledge the supremacy of the ECtHR with regard to human rights. The most important but initially unintended outcome of this strategic interaction was the progressive institutionalization of human rights in the $E U^{84}$.

In this context, the bilateral relation (dialogue) between the ECJ and ECtHR has been developed avoiding contrasts and favoring cooperation.

Indeed, since 1970, when for the first time the ECJ stated that it was also bound to protect fundamental rights ${ }^{85}$, the relationship between Strasbourg and Luxemburg has deeply evolved ${ }^{86}$. The ECJ has usually, though not always, chosen to follow the interpretations of fundamental rights given by the ECtHR, even if the first direct reference to the latter's jurisprudence was in 1996.

Accordingly, the ECtHR has elaborated, starting with its decision $\mathrm{M}$. \& $\mathrm{Co}^{87}$ (at that time the European Commission on Human Rights), a theory providing that even if the European Union Member States remain responsible for violations of fundamental rights committed by international organizations (such as the EU), the protection of fundamental rights within the $\mathrm{EU}$ is substantially equivalent to that guaranteed by the ECHR.

This approach has allowed the ECtHR to declare the judgments concerning Community acts inadmissible. Nevertheless, this trend seemed to change in Cantoni $i^{88}$ and in Matthews ${ }^{89}$.

In the former case the ECtHR reviewed the legality of a French law replicating an EC Directive word by word. In the latter case it found the United Kingdom responsible for the violation of the rights of a citizen residing in Gibraltar, since he was not allowed to vote in the elections of the European Parliament, even if it was Community legislation that could not be unilaterally modified by the United Kingdom.

Finally in its Bosphorusthe ECtHR confirmed the approach adopted in $M \& C o$, but affirming that such presumption of equivalent protection is rebuttable and that it will review the legality of EU acts in cases of manifest deficiencies in the protection of fundamental rights $^{90}$.

As Douglas-Scott suggests, the European human rights landscape provides a strong example of legal pluralism, illustrating a variety of interesting interactions and relationships. The current human rights acquis leaves room for possibilities behind the binary poles of certainty and chaos, anticipating the conceptualization of fuzzy logic, not the constricting "either/or" of a formal mechanistic jurisprudence, but the "both/and" of a less clockwork-like world ${ }^{91}$.

\footnotetext{
${ }^{84}$ F. SCHIMmelfenNIG, Competition and community: constitutional courts, rhetorical action, and the institutionalization of human rights in the European Union, in Journal of European Public Policy, vol. 13, n. 8, (pp. 1247-1264) p.1248.

${ }_{85}$ See also on this point R. TONIATTI, II principio di Rule of Law e la formazione giurisprudenziale del diritto costituzionale dell'Unione Europea, ed. S. GamBINo, Costituzione Italiana e Diritto Comunitario, Giuffrè, Milano, 2002.

${ }^{86}$ Since the Handelsgesellschaft case, the ECJ has established its competence also in the field of human rights protection, thus providing the EU (EEC at that time) with an internal system of guarantees. However, since the EU is not a member of the European Convention on Human Rights the ECJ had to find in the common legal tradition of EU members its source of inspiration. Until now, as the ECJ's and ECtHR's case law show, both Courts tend to remain on a parallel level rather than looking for supremacy. Both judiciaries are aimed to protect fundamental freedoms but at the same time they seem to be very concerned about their authority, so that 'dialogue becomes non-interference'.

${ }^{87}$ Decision of European Commission of Human Rights, M. \& Co. v. Germany, Application n. 13258/87, of 9 February 1990.

${ }^{88}$ Cantoni v. France, ECtHR, Application n. 17862/91, delivered on 22 October 1996.

${ }^{89}$ Matthews $v$ The United Kingdom, ECtHR, Application n. 24883/94, delivered on 18 February 1999.

${ }^{90}$ Bosphorus v. Ireland, ECtHR, Application n. 45036/98, delivered on 30 June 2005.

${ }^{91}$ S. DOUGLAS-SCOTT, Ibid, p.665.
} 
In other words, the behavior of national, supranational, and international judiciaries, in the field of human rights protection, shows how there exists a true dialogic process of judicial interaction, in which each part recognizes the legitimacy of the other without questioning its independence and authority. In this context, the BVerfG 's 'identity decision' can effectively explain how the European system functions. According to German judge:

The elaboration of the principle of democracy by the Basic Law is open to the objective of integrating Germany into an international and European peaceful order. The new shape of political rule which is thereby made possible is not schematically subject to the requirements of a constitutional state applicable on the national level and may therefore not be measured without further ado against the concrete manifestations of the principle of democracy in a Contracting State or Member State. The empowerment to embark on European integration permits a different shaping of political opinion-forming than the one that is determined by the Basic Law for the German constitutional order. This applies as far as the limit of the inalienable constitutional identity (Article 79.3 of the Basic Law). The principle of democratic self-determination and of participation in public authority with due account being taken of equality remains unaffected also by the Basic Law's mandate of peace and integration and the constitutional principle of the openness towards international law (Völkerrechtsfreundlichkeit) ${ }^{92}$ [In addition] The German constitution is oriented towards opening the state system of rule to the peaceful cooperation of the nations and towards European integration. Neither the integration pari passu into the European Union nor the integration into peacekeeping systems such as the United Nations is tantamount to submission to alien powers. Instead, it is a voluntary, mutual commitment pari passu, which secures peace and strengthens the possibilities of shaping policy by joint coordinated action ${ }^{93}$

However, a distinction should be made between different levels of adjudication.

If legitimacy is to be associated only to 'right interpretation', the problem of adjudication would become a secondary issue. Therefore, a court would merely be in charge of concretely addressing claims according to the driving constitutional (national constitutional courts) or European (ECJ), or Conventional (ECtHR) principles.

Nonetheless, legitimacy derives also from the position a democratic institution occupies within a given system in particular when the judiciary adopts a non-majoritarian perspective in its judgments.

Indeed, the legitimacy of a constitutional court is rooted in the constitution and in its 'cultural proximity' with the constitutional order, whereas a supranational or international court might be perceived as collateral to the system, or even extra-system.

The so-called 'European heterarchy' might enhance the degree of protection afforded to individuals, but at the same time might pose a problem of legitimacy. If an order is not organized into a Kelsenian hierarchy, the recognition of the competences typical of an authority, such as a judicial authority, might blur and lead to conflicts in relation to which constitutional powers is competent in addressing one specific issue (e.g. the legislative, or the executive).

\section{Concluding remarks}

As it has been underlined, there are several factors influencing the possibility for judges to enter into a dialogue between Courts. The US Supreme Court is certainly the biggest

\footnotetext{
${ }^{92}$ BVerfG, 2 BvR 182/08, Judgment delivered on 30 June 2009, para.219.
}

${ }^{93}$ BVerfG, 2 BvR 182/08, Judgment delivered on 30 June 2009, para.220. 
example of skepticism, though mitigated by some its members who are more willing to reframe the judicial discourse within a more comprehensive system of values (i.e. the western legal traditions). Conversely, other important Courts (mainly European) are now familiar with the idea of sharing principles through intensification in the use of foreign sources.

Nevertheless, what remains to be explored is the question of how to define which should be 'the relevant case' when judges decide to call upon foreign jurisprudence. It is commonly accepted that the operation of a system of precedent presupposes an ability to identify the relevant precedent ${ }^{\prime}$.

If in a common law system this is a fundamental rule, this assumption becomes even more important in civil law systems where judges are not bound by previous decisions. Thus, what it is required is an organic 'theory of rules of relevance', which could enable judges to distinguish between relevant and irrelevant cases, avoiding criticism by those who believe that there is no space for judicial dialogue in a constitutional system (as Justice Scalia suggests). Therefore, what is needed is a definition of those factors which would be more likely to justify the relevance of a case. Many scholars argue that the factors influencing the rules of relevance consist of a mixture of the principled and pragmatic $^{95}$.

If on the one hand there is an interest in maintaining stability, predictability, judicial economy, and reassuring the public that courts' decisions are not arbitrary, on the other hand, it would be inappropriate to constrain this idem sentire in the field of fundamental freedoms, since human rights tend to have a universalistic value and might not be confined within just one legal order.

However, the problem of appropriateness is not the only one.

There is also a need to clarify whether a judicial decision grounded on foreign precedents is based on 'authoritative reasons', which rely mainly on the legitimacy of the judiciary taken as a guide, and 'substantive reasons' that are advanced by a judge for or against a legal interpretation ${ }^{96}$.

According to Summers, authoritative reasons take the form: 'legal conclusion $X$ is correct because court $Y$ (or judge $Z$ ) so decided. Substantive reasons usually take the form: $X$ is correct because of the following substantive reasons (and judge $Z$ or court $Y$ thinks so too...) $)^{97}$.

Thus, considering that the 'judicial dialogue' will be likely to intensify over the next years, it is of utmost importance to debate questions related to the legitimacy of quoting foreign precedents, in order to promote this process of cultural integration through law.

** Assegnista di Ricerca in diritto costituzionale e comparato, presso il Dipartimento di Scienze Giuridiche (SPGI), Università degli Studi di Padova.

\footnotetext{
${ }^{94}$ F. Schauer, Precedent, in Stanford Law Review, vol. 39, 1987, p.578

${ }^{95}$ C. MCCRUDDEN, supra 4 note, at 514.

${ }^{96}$ C. MCCRUDDEN, supra note 4, at 516.

${ }^{97}$ R.S. Summers, Two Types of Substantive Reasons: The Core of a Theory of Common-Law Justification, in Cornell Law Review, vol. 63, 1978, p. 716.
} 